\title{
Udder health in beef cows and its association with calf growth
}

\author{
Karin Persson Waller ${ }^{1,2^{*}}$, Ylva Persson ${ }^{1,3}$, Ann-Kristin Nyman ${ }^{1}$ and Lena Stengärde ${ }^{4}$
}

\begin{abstract}
Background: Studies outside the Nordic countries have indicated that subclinical mastitis (measured by milk somatic cell count or the California Mastitis Test), intramammary infections (IMI), or blind quarters in beef cows may have negative effects on beef calf growth. Knowledge on prevalence of such udder health problems in Swedish beef cows is scarce. Therefore, the main aim of this study was to investigate subclinical mastitis, IMI and udder conformation in a number of beef cow herds. Production of $\beta$-lactamase in staphylococci was also investigated. Associations between certain cow factors and subclinical mastitis and IMI, and associations between cow and calf factors and 200 day calf weaning weight were also studied. The herds were visited once within a month after calving and once at weaning. Udder examination and quarter milk sampling, for somatic cell count and bacteriology, were performed in 8 to 12 cows per herd and occasion.

Results: Approximately 50\%, $40 \%$ and $10 \%$ of the cows had subclinical mastitis, IMI, and at least one blind quarter, respectively, but the prevalence varied markedly between herds. Intramammary infections (mainly due to staphylococci) were identified in 13-16\% of the milk samples. Less than $5 \%$ of the staphylococcal isolates produced $\beta$-lactamase. Approximately $11 \%$ of the cows sampled twice had the same IMI (mostly Staphylococcus aureus) at both samplings. Cow factors of importance for subclinical mastitis and/or IMI were teat and udder shape, breed, parity, presence of blind quarters, and cow hygiene. No significant associations were found between udder health parameters studied and calf weaning weights.

Conclusions: Subclinical mastitis and IMI, but not blind quarters, were common in beef cows, but the prevalence varied markedly between herds. Most IMI were caused by staphylococci and more than 95\% of those were sensitive to penicillin. Cows with large funnel-shaped teats or pendulous udder after calving, and cows with blind quarters were at risk of having subclinical mastitis and/or IMI. Poor hygiene was also a risk factor for udder health problems. No significant associations were found between udder health and calf weaning weight. More studies on risk factors are warranted to improve advisory services on awareness and prevention of mastitis in beef cows.
\end{abstract}

Keywords: Beef cows, Mastitis, Intra-mammary infections, Blind quarters, Risk factors, Calf weaning weight

\section{Background}

The main goal in beef cow herds is production of healthy calves. To keep calves healthy and fast growing a good start in life is of utmost importance. The milk production of the cow is considered to be an important factor affecting calf growth before weaning [1]. Factors

\footnotetext{
* Correspondence: karin.persson-waller@sva.se

'Department of Animal Health and Antimicrobial Strategies, National

Veterinary Institute (SVA), SE-751 89 Uppsala, Sweden

${ }^{2}$ Department of Clinical Sciences, Swedish University of Agricultural Sciences, SE-750 07 Uppsala, Sweden

Full list of author information is available at the end of the article
}

that reduce milk production may therefore have negative impact on calf weaning weights.

Mastitis, a multifactorial disease often associated with bacterial intramammary infections (IMI), significantly reduces milk production and causes large economical losses in dairy herds both in its clinical and subclinical form. The knowledge on mastitis in beef cows is, however, limited. Most publications have studied subclinical mastitis or IMI, and were performed in the US. Those studies indicate that the prevalence of subclinical mastitis, measured by milk somatic cell count (SCC) or the California Mastitis Test (CMT), or prevalence of IMI may vary markedly between herds [1-11]. As an 
example, the within-herd cow prevalence of IMI varied between $7 \%$ and $66 \%$ in those studies. Studies have indicated that udder health is important for growth of beef calves as subclinical mastitis or IMI in the dams have been associated with a $5-12 \%$ reduction of calf weaning weight $[1-3,8,11]$. Some IMI, especially Staphylococcus aureus, seem to have more negative effects on calf weaning weights than others $[1,8,11]$. Cows with one or more blind quarters may also have calves with reduced growth [2].

It is well known that clinical mastitis sometimes occurs in Swedish beef cows, but the prevalence of subclinical mastitis and IMI is not known and neither is the distribution of different udder pathogens. Moreover, the prevalence of blind quarters is also unknown. Therefore, the main aim of the study was to investigate these udder health indicators in a number of beef cow herds. Production of $\beta$-lactamase in staphylococci was also investigated. In addition, associations between certain cow factors and subclinical mastitis and IMI, as well as associations between cow and calf factors and the adjusted 200 day calf weaning weight were studied.

\section{Methods}

\section{Study design}

Ten beef cow herds were selected based on the following criteria; the herd should be situated in the southern third of Sweden, be affiliated to the official national beef production scheme (KAP; a Swedish acronym meaning meat, breeding and production), have more than 20 cows, have suitable cattle handling facilities, and be willing to participate in the study.

Each herd was visited twice during 2012. At the first visit, in late winter/spring, cows within one month after calving were sampled. The second visit, in autumn, was performed just before weaning. When possible the same cows were sampled at both visits. All cows were housed at the first visit, and at the second visit they were either on pasture or recently housed after the end of the pasture season. The visits were performed by one of three veterinarians from the Swedish Animal Health Service. At each visit the udders of approximately 10 cows were examined by visual assessment and manual palpation. Special attention was given to presence of teat and udder shape, as described previously [12], and presence of blind quarters. Quarter milk samples for analysis of SCC were taken after the first strips of milk had been discarded. Thereafter, milk samples for bacteriology were taken aseptically according to routines for sampling of dairy cows. When possible CMT (scored 1 to 5 , where 1 is healthy and 5 is strong positive reaction) was also performed. The milk samples were cold-stored and sent to the National Veterinary Institute (SVA) for analyses the day after sampling. The cleanliness of the udder, hind legs, and flanks of the cows was scored using a four grade scale where 1 was clean and 4 was very dirty [13]. Herd data (number of cows/year, number of calves/cow/ year), cow data (identity, breed, year of birth, parity, calving date, calf identity) and calf data (identity, mother identity, breed, day of birth, single/twin, birth weight, 200 day weaning weight) were collected in association with the second visit.

The study design was approved by the Regional Committee for Ethics in Animal Research in Uppsala, Sweden (application number C363/11).

\section{Laboratory analyses}

The SCC was evaluated using CMT, and the Delaval Cell Counter (DCC). Bacteriological growth was investigated as described previously [14]. Species differentiation of coagulase-negative staphylococci (CNS) was performed using Maldi-TOF [15]. All staphylococcal isolates were tested for $\beta$-lactamase production using the clover-leaf method [16].

\section{Data editing and statistics}

Subclinical mastitis in an udder quarter was defined as DCC-SCC $\geq 200000 / \mathrm{ml}$. The bacteriological result per quarter was classified as no growth, contamination $(\geq 3$ different bacterial species), and IMI with specific udder pathogens (any IMI, any major IMI (defined as all pathogens except CNS and Corynebacterium bovis), CNS IMI, S. aureus IMI).

The DCC-SCC in quarters with no growth were compared after calving and at weaning using the Student's $\mathrm{t}$-test. Due to a large number of missing values for CMT from the herd investigation only CMT values from the laboratory investigation were used in the statistical evaluation. Comparisons of CMT-scores between quarters with different bacterial findings were performed using the Chi-square test.

Associations between DCC-SCC and bacterial growth on udder quarter level were evaluated using mixed-effect univariable regression analyses, with cow and herd as random factors. Associations between cow factors (breed, parity, hygiene score (1-4), teat shape (normal/funnel shaped), udder shape (normal/pendulous), number of lactating udder quarters $(3 / 4))$ and number of udder quarters with subclinical mastitis (DCC-SCC $\geq 200000 / \mathrm{ml}$ or CMT 3-5) or IMI (any IMI, any major IMI, CNS IMI, S. aureus IMI) per cow at each of the two samplings were evaluated using the Fisher's exact test.

Associations between the dependent variable calf 200 day weaning weight, and the independent variables subclinical mastitis (number of quarters with DCC-SCC $\geq 200$ 000/ml $(0, \geq 1)$ ) or IMI in one or several quarters per cow (number of quarters with any IMI $(0,1,2,3-4$, or $0, \geq 1)$, number of quarters with any major IMI $(0, \geq 1)$, number of quarters with CNS IMI $(0,1,2-3$, or $0, \geq 1)$, number of quarters 
with $S$. aureus IMI $(0,1,2-3$, or $0, \geq 1)$ at each sampling occasion), were investigated using mixed-effect univariable and multivariable regression analyses (with cow and herd as random factors). Moreover, calf factors (gender, twin (yes/no), birth weight), general cow factors (breed, parity) and cow health factors (hygiene score, number of lactating quarters, teat and udder shape) were also included as independent variables. For the multivariable models collinearity between the independent variables was assessed pair-wise by calculation of Spearman rank correlations. If there was proof of collinearity $(\mathrm{r} \leq 0.70)$ the variable with lowest $P$-value in the univariable analysis was selected. Moreover, in all the multivariable models biologically plausible two-way interactions between the main effects were tested. The model fit of the multivariable analyses was tested by visual examination of diagnostic plots [17]. All statistical analyses were performed using Stata (Release 11.2; College Station, TX, USA: StataCorp LP).

\section{Results}

The median number of cows per herd year 2012 was 58 (range 15-103). Breeds present were Simmental (4 herds), Hereford ( 4 herds) and Limousin ( 2 herds). Two of the Simmental herds and one of the Hereford herds also had cross-bred cows. Eight herds housed the cows in cold loose housing systems during winter while one herd had a tiedup system and one herd had a combination of tied-up and loose housing systems during winter. In all herds the cows were on pasture from mid April/end of May to end of September/end of November.

The number of sampled cows per herd and occasion varied between 8 and 12. A total of 109 individuals were examined of which 83 (76\%) participated at both samplings. The distribution of breeds were 37 (34\%) Hereford, 34 (31\%) Simmental, 21 (19\%) Limousin, and 17 (16\%) crossbreeds. Most (64\%) cows were in their first to third lactation. The cow hygiene score was, on average, 2.1 (SD 0.6) and 1.8 (SD 0.7) at the first and second visit, respectively. The median cow hygiene score was 2 at both occasions.

Prevalence of subclinical mastitis, IMI and blind quarters At quarter level, 20 to $30 \%$ of the quarters had a DCCSCC indicating subclinical mastitis, and around 15\% of the quarters had IMI, while blind quarters were rather uncommon (Table 1). A total of 332 quarters were sampled twice and 19 (6.1\%) of those quarters had subclinical mastitis at both occasions. Overall, IMI was identified in 13\% and $16 \%$ of the quarters after calving and at weaning, respectively (Figure 1). Most IMI were staphylococci (CNS or $S$. aureus), and the majority of those ( $94.6 \%$ and $95.4 \%$, respectively) did not produce $\beta$-lactamase. Seven CNS species (S. chromogenes, S. haemolyticus, S. hyicus, S. sciuri, S. simulans, S. succinus, and S. xylosus) were identified. The majority (66\%) of the CNS isolates was S. chromogenes, and the second most common species was $S$. sciuri $(18 \%)$. The other CNS species each constituted less than $4 \%$ of the isolates.

Results on cow level are given in Table 2. Approximately $50 \%$ of the cows had subclinical mastitis in at least one udder quarter, while around $40 \%$ and $16 \%$ of the cows had any IMI or $S$. aureus IMI, respectively. Approximately $11 \%$ of the cows sampled twice had $S$. aureus IMI at both samplings. Around 10\% of the cows had one blind quarter, and none of the cows had more than one blind quarter. As shown in Table 3, the prevalence of the different outcomes varied markedly among herds.

\section{Comparisons of DCC-SCC after calving and at weaning}

The average DCC-SCC in quarters with no growth after calving and at weaning was 147 000/ml (SD 419 000/ml) and $196000 / \mathrm{ml}$ (SD $319000 / \mathrm{ml})$, respectively, and did not differ significantly (Student's t-test, $P=0.41$ ). The corresponding median SCC was $44000 / \mathrm{ml}$ and $52000 /$ $\mathrm{ml}$, respectively.

\section{Associations between DCC-SCC or CMT and bacterial findings}

The DCC-SCC varied markedly in quarters with IMI, but was significantly higher in IMI quarters than in quarters with no growth (Table 4). Quarters infected with CNS had lower DCC-SCC than quarters with other IMI. Quarters with S. chromogenes had higher SCC (median $271000 / \mathrm{ml}$ ) than quarters infected with other CNS (median 70 000/ml; Student's t-test, $P=0.005$ ).

Table 1 Prevalence of udder quarters with subclinical mastitis (SCC $\geq 200$ 000/ml), intramammary infection (IMI) or no milk production (blind quarter) in beef cows investigated within a month after calving and at weaning in 10 beef cow herds

\begin{tabular}{|c|c|c|c|c|}
\hline \multirow[t]{2}{*}{ Variable } & \multicolumn{2}{|l|}{ After calving ( $n=104$ cows) } & \multicolumn{2}{|l|}{ At weaning ( $n=90$ cows) } \\
\hline & $\begin{array}{l}\text { Total number of investigated } \\
\text { quarters }\end{array}$ & $\begin{array}{l}\text { Number (\%) of affected } \\
\text { quarters }\end{array}$ & $\begin{array}{l}\text { Total number of investigated } \\
\text { quarters }\end{array}$ & $\begin{array}{l}\text { Number (\%) of affected } \\
\text { quarters }\end{array}$ \\
\hline $\mathrm{SCC} \geq 200000 / \mathrm{ml}$ & 396 & $72(18.2)$ & 351 & $103(29.3)$ \\
\hline IMI & 403 & $56(13.9)$ & 351 & $56(15.9)$ \\
\hline Blind quarter & 416 & $11(2.6)$ & 358 & $9(2.8)$ \\
\hline
\end{tabular}



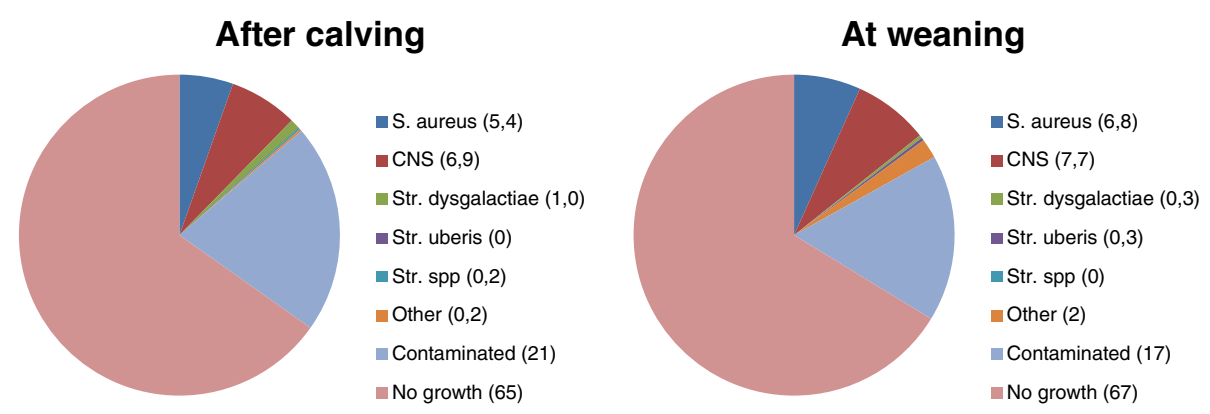

Figure 1 Bacterial findings in quarter milk samples. Proportions (\%) of udder quarter milk samples from beef cows with different types of bacterial findings within one month after calving $(n=403)$ and at weaning $(n=351)$.

The proportion of udder quarters with CMT 3-5 (indicating sub-clinical mastitis) was significantly $(P<0.0001)$ higher in quarters with IMI (mean score 2.04 (SD 1.22); median score 2) than in quarters with no growth (mean score 1.34 (SD 0.68); median score 1). The proportion of quarters with no growth, any IMI, any major IMI, CNS IMI, and S. aureus IMI having CMT 3-5 was 4.3\%, 27.3\%, $38.9 \%, 16.1 \%$ and $40.5 \%$, respectively.

\section{Associations between cow factors and prevalence of subclinical mastitis or IMI at cow level}

Cow factors studied were breed, parity, hygiene, teat and udder shape, and presence of blind quarters. Factors having significant effects on the outcome variables after calving and at weaning are presented in Tables 5 and 6, respectively. Presence of quarters with subclinical mastitis after calving was more common in cows with large funnel-shaped teats or pendulous udder than in cows with normal teat and udder shape. Presence of any IMI was also more common in cows with large funnel-shaped teats. Hereford and Simmental had the lowest and highest, respectively, proportions of cows with subclinical mastitis after calving. Cows in the first and second lactation had lower prevalence of IMI after calving than older cows. IMI was less common in cows with four lactating quarters than in cows with one blind quarter. Cows with poor hygiene

Table 2 Cow level prevalence of beef cows with at least one udder quarter with subclinical mastitis (SCC $\geq \mathbf{2 0 0}$ $000 / \mathrm{ml}$ ), intramammary infection (IMI) of any bacteria, Staphylococcus aureus IMI, or no milk production (blind quarter) within a month after calving and at weaning in 10 beef cow herds

\begin{tabular}{lll}
\hline Variable & $\begin{array}{l}\text { Cows after calving } \\
(\mathbf{n}=\mathbf{1 0 4}) \mathbf{n}(\%)\end{array}$ & $\begin{array}{l}\text { Cows at weaning } \\
(\mathbf{n}=\mathbf{9 0}) \mathbf{n}(\%)\end{array}$ \\
\hline SCC $\geq 200000 / \mathrm{ml}$ & $48(46.1)$ & $52(57.8)$ \\
Any IMI & $42(40.4)$ & $38(42.2)$ \\
S. aureus IMI & $15(14.4)$ & $17(18.9)$ \\
Blind quarter & $11(10.6)$ & $8(8.9)$ \\
\hline
\end{tabular}

score had more CNS IMI after calving, and more subclinical mastitis and IMI at weaning than clean cows.

\section{Associations between cow and calf factors, and 200 day calf weaning weight}

The multivariable analyses revealed that none of the cow udder health factors had any significant $(P>0.05)$ association with calf weaning weight. Factors that had a significant effect on weaning weight were gender of the calf $(P<0.001)$, weight at birth $(P=0.004)$ and breed $(P<0.001)$. The weaning weight increased with $33 \mathrm{~kg}$ if the calf was a male, and with $1.7 \mathrm{~kg}$ per $\mathrm{kg}$ increasing weight at birth. The weaning weight was $82 \mathrm{~kg}, 18 \mathrm{~kg}$ and $68 \mathrm{~kg}$ higher in cross-breeds, Limousin and Simmental, respectively, than in Hereford. The significant factors explained $69 \%$ of the variation in calf weaning weight.

\section{Discussion}

The results of this study show that subclinical mastitis and IMI were common in the investigated beef cows. A somewhat higher proportion of cows was affected by subclinical mastitis than by IMI, but the proportions of affected cows varied markedly between herds. The proportions of beef cows with subclinical mastitis or IMI after calving and at weaning were similar. The large variation between herds was in line with studies from other countries [1-11]. According to Newman et al. [8] and Duenas et al. [2] the prevalence of IMI is highest at the end of lactation, but in the present study no such difference was observed between sampling occasions. In this study, as well as in other studies [2,9], both young and old cows were affected, but the prevalence increased with increasing parity. The most common IMI found were CNS and $S$. aureus, which is in line with previous studies $[1,2,4,6,8,9]$.

Regarding cow factors of importance for the prevalence of subclinical mastitis or IMI the results indicate that large funnel-shaped teats, pendulous udder, presence of blind quarters, and poor hygiene are risk factors for udder health problems. The importance of teat and 
Table 3 Herd level prevalence of beef cows with at least one udder quarter with subclinical mastitis (SCC $\geq 200$ 000/ml), intramammary infection (IMI) of any bacteria, Staphylococcus aureus IMI, or no milk production (blind quarter) within a month after calving and at weaning in 10 beef cow herds

\begin{tabular}{|c|c|c|c|c|}
\hline \multirow[t]{2}{*}{ Variable } & \multicolumn{2}{|l|}{ After calving } & \multicolumn{2}{|l|}{ At weaning } \\
\hline & $\begin{array}{l}\text { Number of herds with } \\
\geq 1 \text { cow affected }\end{array}$ & $\begin{array}{l}\text { Proportion of cows affected per } \\
\text { herd median (range) }\end{array}$ & $\begin{array}{l}\text { Number of herds with } \\
\geq 1 \text { cow affected }\end{array}$ & $\begin{array}{l}\text { Proportion of cows affected per } \\
\text { herd median (range) }\end{array}$ \\
\hline SCC $\geq 200000 / \mathrm{ml}$ & 10 & $52(18-67)$ & 9 & $69(0-90)$ \\
\hline Any IMI & 9 & $38(0-67)$ & 10 & $43(22-60)$ \\
\hline S. aureus IMI & 7 & $13(0-33)$ & 9 & $21(0-33)$ \\
\hline Blind quarter & 6 & $9(0-40)$ & 4 & $0(0-40)$ \\
\hline
\end{tabular}

udder shape is in line with recommendations from the USA [12]. The fact that cows having blind quarters had more problems with subclinical mastitis and IMI in the other udder quarters is likely a result of the spread of an IMI from the blind quarter to the other quarters within the udder. An association between blind quarters and poor udder health was also found in previous studies $[2,6]$. The results indicate that the risk for udder health problems within a herd can be reduced by culling cows that have large funnel-shaped teats or pendulous udders after calving, and cows with blind quarters. Other risk factors for poor udder health in beef cows that have been suggested are holding cows within a limited space, presence of many flies around the cows, cross-suckling calves, and wet and muddy weather [18], but those factors were not investigated in the present study.

In the present study, a SCC cut-off of $200000 / \mathrm{ml}$ was chosen as the definition of subclinical mastitis. This cutoff is based on studies on dairy cows $[19,20]$, and it is not known if the cut-off is appropriate also for beef cows. Moreover, only one milk sample per quarter was taken at each sampling period for evaluation of IMI, which might increase the risk of false negative results. It was not, however, practically possible to take several samples in this study. The results indicate, however, that the SCC cut-off and the sampling procedure were adequate as udder quarters with no growth mostly had SCC below $200000 / \mathrm{ml}$, and that the SCC was significantly higher in quarters with IMI. Differences in SCC between quarters with different types of IMI were also as expected based on studies on dairy cows.

In contrast to earlier studies [1-3,8,11] a significant association between subclinical mastitis or IMI, and 200 day calf weaning weight was not observed. However, in line with our results, Paape et al. [9] did not find any effect of IMI on calf weaning weight, and Simpson et al. [10] found no difference in weaning weights between calves from Simmental cows with low or high SCC. The

Table 4 Associations between somatic cell counts (SCC x1000/mI) and intramammary infection (IMI) in udder quarter milk samples taken from beef cows within a month after calving and at weaning in 10 beef cow herds

\begin{tabular}{|c|c|c|c|c|c|c|}
\hline \multirow[t]{2}{*}{ Bacterial findings } & \multicolumn{3}{|l|}{ After calving } & \multicolumn{3}{|l|}{ At weaning } \\
\hline & Median SCC ( $50 \%$ central range) & $\mathbf{n}$ & $P$-value & Median SCC (50\% central range) & $\mathbf{n}$ & $P$-value \\
\hline \multicolumn{7}{|l|}{$\mathrm{IMI}$} \\
\hline No & $48(22-104)$ & 314 & & $44(13-188)$ & 295 & \\
\hline Yes & $346(75-1113)$ & 50 & $<0.0001$ & $303(58-1041)$ & 56 & $<0.0001$ \\
\hline \multicolumn{7}{|l|}{$\mathrm{IMI}$, not $\mathrm{CNS}^{\mathrm{a}}$} \\
\hline No & $48(22-104)$ & 312 & & $44(13-188)$ & 295 & \\
\hline Yes & $820(185-2605)$ & 24 & $<0.0001$ & $370(75-1946)$ & 29 & $<0.0001$ \\
\hline \multicolumn{7}{|l|}{ IMI } \\
\hline No & $48(22-104)$ & 314 & & $44(13-188)$ & 295 & \\
\hline $\mathrm{CNS}^{\mathrm{a}}$ & $106(66-425)$ & 26 & & $218(30-802)$ & 27 & \\
\hline S. aureus & $820(185-2487)$ & 20 & & $419(97-2318)$ & 21 & \\
\hline Other & $1782(353-3208)$ & 4 & $<0.0001^{b}$ & $239(37-677)$ & 8 & $<0.0001^{c}$ \\
\hline
\end{tabular}

${ }^{\mathrm{a}} \mathrm{CNS}=$ coagulase negative staphylococci.

${ }^{\mathrm{b}} \mathrm{CNS}$, Staphylococcus aureus and other pathogens (only Streptococcus dysgalactiae) had significantly higher SCC than no IMl; S. aureus and other pathogens had significantly higher SCC than CNS.

${ }^{\mathrm{C} C N S}$ and S. aureus had significantly higher SCC than no IMl; S. aureus had significantly higher SCC than CNS and other pathogens (2 Escherichia coli, 1 Serratia marcescens, 1 Str. dysgalactiae, 1 Str. uberis and 3 coagulase positive staphylococci (not S. aureus). 
Table 5 Cow factors with significant $(P<0.10)$ effect on prevalence of subclinical mastitis (SCC $\geq 200000 / \mathrm{ml})$ or intramammary infections (IMI) in beef cows examined within one month after calving in 10 beef cow herds

\begin{tabular}{|c|c|c|c|c|c|c|}
\hline \multirow{2}{*}{$\begin{array}{l}\text { Outcome } \\
\text { Quarters with SCC } \geq 200000 / \mathrm{ml}\end{array}$} & \multirow{2}{*}{ Cow factor } & \multirow[t]{2}{*}{ Class } & \multicolumn{3}{|c|}{$\begin{array}{l}\text { Number of cows with different numbers of } \\
\text { quarters affected (QA) }\end{array}$} & \multirow[t]{2}{*}{$\begin{array}{l}\text { Total number } \\
P \text {-values }\end{array}$} \\
\hline & & & $0 \mathrm{QA}$ & $1 \mathrm{QA}$ & $\geq 2 \mathrm{QA}$ & \\
\hline & Breed & Hereford & 23 & 12 & 0 & 35 \\
\hline & & Cross bred & 8 & 5 & 4 & 17 \\
\hline & & Limousin & 12 & 3 & 6 & 21 \\
\hline & & Simmental & 12 & 9 & 8 & 29 \\
\hline & & Total & 55 & 29 & 18 & $P=0.008$ \\
\hline & Teat shape & Normal & 37 & 12 & 8 & 57 \\
\hline & & Large funnel-shaped & 16 & 15 & 10 & 41 \\
\hline & & Total & 53 & 27 & 18 & $P=0.038$ \\
\hline & Udder shape & Normal & 48 & 17 & 15 & 80 \\
\hline & & Pendulous & 7 & 12 & 3 & 22 \\
\hline & & Total & 55 & 29 & 18 & $P=0.012$ \\
\hline \multirow[t]{7}{*}{ Quarters with $\mathrm{CMT}^{\mathrm{a}} \geq 3$} & & & $O Q A$ & $1-4 \mathrm{QA}$ & & \\
\hline & Teat shape & Normal & 52 & 5 & & 57 \\
\hline & & Large funnel-shaped & 27 & 14 & & 41 \\
\hline & & Total & 79 & 19 & & $P=0.004$ \\
\hline & Udder shape & Normal & 68 & 12 & & 80 \\
\hline & & Pendulous & 14 & 8 & & 22 \\
\hline & & Total & 82 & 20 & & $P=0.035$ \\
\hline \multirow[t]{14}{*}{ Quarters with any IMI } & & & $0 \mathrm{QA}$ & $1 \mathrm{QA}$ & $\geq 2 \mathrm{QA}$ & \\
\hline & Parity & 1 & 22 & 6 & 1 & 29 \\
\hline & & 2 & 13 & 2 & 3 & 18 \\
\hline & & 3 & 6 & 7 & 3 & 16 \\
\hline & & 4 & 8 & 7 & 0 & 15 \\
\hline & & $5-6$ & 8 & 5 & 3 & 16 \\
\hline & & $\geq 7$ & 4 & 3 & 1 & 8 \\
\hline & & Total & 61 & 30 & 11 & $P=0.083$ \\
\hline & Teat shape & Normal & 39 & 13 & 5 & 57 \\
\hline & & Large funnel-shaped & 19 & 16 & 6 & 41 \\
\hline & & Total & 58 & 29 & 11 & $P=0.094$ \\
\hline & Blind quarter present & No & 58 & 25 & 8 & 91 \\
\hline & & Yes & 3 & 5 & 3 & 11 \\
\hline & & Total & 61 & 30 & 11 & $P=0.031$ \\
\hline \multirow[t]{4}{*}{ Quarters with any major IMI } & & & 0 QA & $1 \mathrm{QA}$ & $\geq 2 \mathrm{QA}$ & \\
\hline & Blind quarter present & No & 77 & 11 & 3 & 91 \\
\hline & & Yes & 6 & 3 & 2 & 11 \\
\hline & & Total & 83 & 14 & 5 & $P=0.025$ \\
\hline \multirow[t]{5}{*}{ Quarters with CNS ${ }^{\mathrm{b}}$ IMI } & & & $0 \mathrm{QA}$ & $\geq 1 \mathrm{QA}$ & & \\
\hline & Hygiene & 1 & 15 & 1 & & 16 \\
\hline & & 2 & 43 & 21 & & 64 \\
\hline & & $3-4$ & 18 & 3 & & 3 \\
\hline & & Total & 76 & 25 & & $P=0.048$ \\
\hline
\end{tabular}


Table 5 Cow factors with significant $(P<0.10)$ effect on prevalence of subclinical mastitis (SCC $\geq 200000 / \mathrm{ml})$ or intramammary infections (IMI) in beef cows examined within one month after calving in 10 beef cow herds (Continued)

\begin{tabular}{|c|c|c|c|c|c|}
\hline \multirow[t]{4}{*}{ Quarters with S. aureus IMI } & & & 0 QA & $\geq 1 \mathrm{QA}$ & \\
\hline & Blind quarter present & No & 80 & 11 & 91 \\
\hline & & Yes & 7 & 4 & 11 \\
\hline & & Total & 87 & 15 & $P=0.054$ \\
\hline
\end{tabular}

${ }^{\mathrm{a}} \mathrm{CMT}=$ California Mastitis Test.

${ }^{\mathrm{b}} \mathrm{CNS}=$ coagulase negative staphylococci.

differences between studies may be due to differences in study design, such as number of herds and animals, breeds included, or statistical methods. It is, for example, likely that the effect of a decreased milk production on calf growth is less pronounced in breeds producing more milk. In this study, gender of calf, breed and weight at birth had substantial influence on the weaning weight. Factors like quality and amounts of feed or pasture may also be important, but this was not investigated. As the number of herds and cows included in the present study was relatively small the results should be interpreted with caution.

\section{Conclusions}

Subclinical mastitis and IMI, but not blind quarters, was common in beef cows both within one month after calving and at weaning, but the prevalence varied markedly among herds. Only around $11 \%$ of the cows sampled twice had the same IMI (mainly $S$. aureus), indicating persistent IMI, at both samplings. Most IMI were caused by staphylococci and more than $95 \%$ of those were sensitive to penicillin. Cows that had large funnel-shaped teats or pendulous udders after calving, and cows with blind quarters were at risk of having subclinical mastitis

Table 6 Cow factors with significant $(P<0.10)$ effect on prevalence of subclinical mastitis $($ SCC $\geq 200000 / \mathrm{ml})$ or intramammary infections (IMI) in beef cows examined at weaning in 10 beef cow herds

\begin{tabular}{|c|c|c|c|c|c|c|}
\hline \multirow{2}{*}{$\begin{array}{l}\text { Outcome } \\
\text { Quarters with SCC } \geq 200 \text { 000/ml }\end{array}$} & \multirow{2}{*}{$\begin{array}{l}\text { Cow factor } \\
\text { Hygiene }\end{array}$} & \multirow[t]{2}{*}{ Class } & \multicolumn{3}{|c|}{$\begin{array}{l}\text { Number of cows with different numbers of quarters } \\
\text { affected }(Q A)^{\mathrm{a}}\end{array}$} & \multirow[t]{2}{*}{$\begin{array}{l}\text { Total numbers } \\
P \text {-values }\end{array}$} \\
\hline & & & $0 \mathrm{QA}$ & $1 \mathrm{QA}$ & $\geq 2 \mathrm{QA}$ & \\
\hline & & 1 & 9 & 8 & 11 & 28 \\
\hline & & 2 & 29 & 13 & 11 & 53 \\
\hline & & $3-4$ & 1 & 4 & 4 & 9 \\
\hline & & Total & 39 & 25 & 26 & $P=0.051$ \\
\hline \multirow[t]{5}{*}{ Quarters with $\mathrm{CMT}^{\mathrm{b}} \geq 3$} & Hygiene & & $0 Q A$ & $1-4 \mathrm{QA}$ & & \\
\hline & & 1 & 16 & 10 & & 26 \\
\hline & & 2 & 40 & 8 & & 48 \\
\hline & & $3-4$ & 5 & 4 & & 9 \\
\hline & & Total & 61 & 22 & & $P=0.044$ \\
\hline \multirow[t]{5}{*}{ Quarters with any IMI } & Hygiene & & $0 \mathrm{QA}$ & $1 \mathrm{QA}$ & $\geq 2 \mathrm{QA}$ & \\
\hline & & 1 & 13 & 7 & 8 & 28 \\
\hline & & 2 & 36 & 12 & 5 & 53 \\
\hline & & $3-4$ & 3 & 4 & 2 & 9 \\
\hline & & Total & 52 & 23 & 15 & $P=0.067$ \\
\hline \multirow[t]{4}{*}{ Quarters with major IMI } & Blind quarter present & & 0 QA & $1 \mathrm{QA}$ & $\geq 2 \mathrm{QA}$ & \\
\hline & & No & 65 & 13 & 4 & 82 \\
\hline & & Yes & 4 & 1 & 3 & 8 \\
\hline & & Total & 69 & 14 & 7 & $P=0.026$ \\
\hline \multirow[t]{4}{*}{ Quarters with S. aureus IMI } & Blind quarter present & & 0 QA & $\geq 1 \mathrm{QA}$ & & \\
\hline & & No & 70 & 12 & & 82 \\
\hline & & Yes & 4 & 4 & & 8 \\
\hline & & Total & 74 & 16 & & $P=0.031$ \\
\hline
\end{tabular}


and/or IMI. Poor hygiene was also a risk factor for udder health problems. In this study, no significant associations were found between udder health and calf weaning weight. The high prevalence of subclinical mastitis and IMI, and the marked variation in herd prevalence indicate that more studies on risk factors are warranted to improve advisory services on awareness and prevention of mastitis in beef cows.

\section{Abbreviations}

CMT: California mastitis test; DCC-SCC: DeLaval cell counter somatic cell count; IMI: Intramammary infection; SCC: Somatic cell count.

\section{Competing interests}

The authors declare that they have no competing interests.

\section{Authors' contributions}

KPW conceived of the study, was responsible for its coordination and design, and drafted the manuscript. YP participated in the design and coordination of the study, and helped to draft the manuscript. AN performed the statistical analyses and helped to draft the manuscript. LS participated in coordination, data collection and design of the study. All authors read and approved the final manuscript.

\section{Acknowledgments}

The Swedish Farmers' Foundation for Agricultural Research is gratefully acknowledged for financing the study. The authors also wish to thank Maria Persson, National Veterinary Institute, for performing the laboratory analyses, and Katinca Fungbrant and Virpi Welling, Swedish Animal Health Service, for performing some of the herd visits.

\section{Author details}

'Department of Animal Health and Antimicrobial Strategies, National Veterinary Institute (SVA), SE-751 89 Uppsala, Sweden. ${ }^{2}$ Department of Clinical Sciences, Swedish University of Agricultural Sciences, SE-750 07 Uppsala, Sweden. ${ }^{3}$ Växa Sverige, Box 288, SE-751 05 Uppsala, Sweden.

${ }^{4}$ Swedish Animal Health Service, SE-391 28 Kalmar, Sweden.

Received: 15 November 2013 Accepted: 29 January 2014

Published: 30 January 2014

\section{References}

1. Nickerson SC, Owens WE, DeRouen SM: Mastitis prevalence in first calf beef heifers and effect on calf weaning weight. Large Anim Pract 2000, 21:20-23.

2. Duenas ML, Paape MJ, Wettemann RP, Douglass LW: Incidence of mastitis in beef cows after intramuscular administration of oxytetracycline. J Anim Sci 2001, 79:1996-2005.

3. Haggard DL, Farnsworth RJ, Springer JA: Subclinical mastitis of beef cows. JAVMA 1983, 182:604-606.

4. Hunter AC, Jeffrey DC: Subclinical mastitis in suckler cows. Vet Rec 1975, 96:442-447.

5. Kirkbride CA: Mastitis in beef cows. JAVMA 1977, 170:1141-1142.

6. Lents CA, Wettemann RP, Paape MJ, Vizcarra JA, Looper ML, Buchanan DS, Lusby KS: Efficacy of intramuscular treatment of beef cows with oxytetracycline to reduce mastitis and to increase calf growth. J Anim Sci 2002, 80:1405-1412.

7. Lents CA, Wettemann RP, Paape MJ, Looper ML, Buchanan DS: Effects of dry cow treatment of beef cows on pathogenic organisms, milk somatic cell counts, and calf growth during the subsequent lactation. J Anim Sci 2008, 86:748-755.

8. Newman MA, Wilson LL, Cash EH, Eberhart RJ, Drake TR: Mastitis in beef cows and its effects on calf weight gain. J Anim Sci 1991, 69:4259-4272.

9. Paape MJ, Duenas MI, Wettemann RP, Douglas LW: Effects of intramammary infection and parity on calf weaning weight and milk quality in beef cows. J Anim Sci 2000, 78:2508-2514

10. Simpson RB, Wesen DP, Anderson KL, Armstrong JD, Harvey RW: Subclinical mastitis and milk production in primiparous Simmental cows. J Anim Sci 1995, 73:1552-1558.
11. Watts JL, Pankey JW, Oliver WM, Nickerson SC, Lazarus AW: Prevalence and effects of intramammary infection in beef cows. J Anim Sci 1986, 62:16-20.

12. Selk G: Evaluate udder soundness now to use as culling criteria next fall. Drovers Cattle Netw 2011. http://www.cattlenetwork.com/cattle-resources/ cattle-breeds/angus/Evaluate-udder-soundness-now-to-use-as-cullingcriteria-next-fall-122452644.html .

13. Anonymous: Vejledning til hygiejnevurdering. https://www.landbrugsinfo.dk/ Kvaeg/Filer/hygiejne.PDF; accessed 31-10-2013.

14. Ericsson Unnerstad H, Lindberg A, Persson Waller K, Ekman T, Artursson K, Nilsson-Öst M, Bengtsson B: Microbial etiology of acute clinical mastitis and agent-specific risk factors. Vet Microbiol 2009, 137:90-97.

15. Van Veen S, Claas E, Kuijper E: Ongoing revolution in bacteriology: Routine identification of bacteria by matrix-assisted laser desorption ionization time-of-flight mass spectrometry. Clin Inf Disease 2009, 49:543-551.

16. Bryan LE, Godfrey AJ: Beta-lactam antibiotics: mode of action and bacterial resistance. In Antibiotics in Laboratory Medicine. Edited by Lorian V. Baltimore, USA: William \& Wilkins:648.

17. Dohoo IR, Martina W, Stryhn H: Veterinary Epidemiologic Research. 2nd edition. Charlottestown, Canada: VER Inc; 2010

18. Mayer J: Mastitis. ANGUS Journal 2001, 133-136. http://www.angusjournal. com/ArticlePDF/0801aj_Mastitis.pdf.

19. Dohoo IR, Leslie KW: Evaluation of changes in somatic cell counts as indicators of new intramammary infections. Prev Vet Med 1991, 10:225-237.

20. Schukken YH, Wilson DJ, Welcome F, Garrison-Tikofsky L, Gonzalez RN: Monitoring udder health and milk quality using somatic cell counts. Vet Res 2003, 34:579-596.

doi:10.1186/1751-0147-56-9

Cite this article as: Persson Waller et al:: Udder health in beef cows and its association with calf growth. Acta Veterinaria Scandinavica 2014 56:9.

\section{Submit your next manuscript to BioMed Central and take full advantage of:}

- Convenient online submission

- Thorough peer review

- No space constraints or color figure charges

- Immediate publication on acceptance

- Inclusion in PubMed, CAS, Scopus and Google Scholar

- Research which is freely available for redistribution 